\title{
ZARZĄDZANIE KREDYTOWYMI EKSPOZYCJAMI DEWIZOWYMI - PERSPEKTYWA KLIENTÓW BANKU
}

Z arys treści. Opracowanie dotyczy problematyki zarządzania kredytowymi ekspozycjami dewizowymi, tworzonymi w wyniku udzielania mieszkaniowych kredytów hipotecznych w walutach obcych. Kredyty te stanowią obecnie główną grupę aktywów bankowych, obciążających zarówno banki, jak i ich klientów wieloma rodzajami ryzyka. Z punktu widzenia klientów największe znaczenie będą miały: ryzyko zmiany kursu walutowego, ryzyko niskiego wkładu własnego oraz ryzyko zmiany stóp procentowych. Możliwość zarządzania tym ryzykiem w przypadku klientów banków jest ograniczona właściwie tylko do kilku instrumentów i technik finansowych.

Słow a kluczowe: ekspozycja, ryzyko, rekomendacja KNF, ustawa ,antyspreadowa".

\section{WSTĘP}

Kredyty mieszkaniowe stanowią współcześnie najważniejszą grupę aktywów sektora bankowego w Polsce. Ich bardzo dynamiczny wzrost obserwowany był zwłaszcza w latach 2004-2008, tzn. w okresie boomu na rynku nieruchomości. Aktywność banków w procesie kredytowania hipotecznego była wówczas szczególnie wysoka, a kredyty przyznawane były na bardzo liberalnych zasadach. Banki korzystały przy tym z efektu szybkiego wzrostu całej gospodarki, większego zatrudnienia oraz rosnących wynagrodzeń umożliwiających coraz lepszą obsługę zadłużenia. Poprawiająca się sytuacja materialna społeczeństwa, relatywnie niskie ceny mieszkań i materiałów budowlanych, a także zmiana stawki podatku VAT na materiały budowlane po przystąpieniu Polski do UE, spowodowały 
wzmożone zainteresowanie kupnem mieszkań lub budową domów. Ponieważ polska gospodarka w pierwszej dekadzie XX w. rozwijała się szybciej od wielu gospodarek wysoko rozwiniętych krajów Europy Zachodniej i charakteryzowała się przy tym wyższą inflacją, stąd cena pieniądza na polskim rynku była również wyższa w stosunku do cen rynku międzybankowego strefy euro oraz Szwajcarii. Ze względu na znaczącą różnicę w odsetkach wieloletnich kredytów hipotecznych w walucie polskiej oraz walutach obcych, a także ze względu na relatywnie łatwą dostępność tych walut na rynkach międzynarodowych, polscy kredytobiorcy zaczęli masowo sięgać po walutowe kredyty hipoteczne, tworząc kredytowe ekspozycje dewizowe o niespotykanej wcześniej wartości. Banki komercyjne, mając zapewnione tanie refinansowanie ze strony banków zagranicznych, zaczęły promować wymienione kredyty szczególnie aktywnie, istotnie zarabiając na prowizjach i opłatach z tytułu ich sprzedaży. Przy okazji podmioty te znacząco podniosły wartość kredytowania w stosunku do wartości nieruchomości (LtV), zaniżyły koszty utrzymania w procesie weryfikacji zdolności kredytowej klientów oraz dokonywały ograniczonej oceny tej zdolności. Proces liberalnego kredytowania w walutach obcych istotnie wspierał bardzo szybki wzrost cen nieruchomości stanowiących zabezpieczenie kredytów oraz czteroletni trend umacniania się polskiego złotego w stosunku do walut obcych. W efekcie kredyty hipoteczne denominowane lub indeksowane w stosunku do walut obcych stały się najważniejszym rodzajem kredytów w sektorze bankowym w Polsce, koncentrując na koniec 2008 r. 22,3\% (Sektor, 2009) wartości wszystkich kredytów udzielonych sektorowi niefinansowemu. Nadejście kryzysu finansowego połączone z odwróceniem długoterminowych trendów wzrostowych na rynku kapitałowym oraz walutowym spowodowało, że klienci banków tworzący kredytowe ekspozycje dewizowe zaczęli zmagać się z problemem nagłej materializacji ryzyka zmiany kursów walut. Przede wszystkim zaczęli oni ponosić dodatkowe koszty niespotykanego wcześniej wzrostu kursu franka szwajcarskiego i euro, a także koszty ustanowienia dodatkowych zabezpieczeń (ubezpieczeń), których zażądały banki w warunkach nagłego wzrostu wskaźnika LtV kredytów walutowych. Wobec istotnie zwiększonego ryzyka finansowania w walutach obcych, generującego bardzo silny wzrost kosztów kredytów, oraz groźby przełożenia tego ryzyka na ryzyko kredytowe, a następnie ryzyko systemowej niewypłacalności całego sektora bankowego, celem niniejszego opracowania jest analiza ryzyka wynikającego z dewizowych ekspozycji kredytowych, ocena wpływu tego ryzyka na banki krajowe oraz przedstawienie narządzi i metod zarządzania tym ryzykiem w Polsce z perspektywy klientów banków. Przeprowadzona zostanie również ocena uchwalonej w 2011 r. nowelizacji prawa bankowego określanej ustawą ,antyspreadową" (Ustawa, 2011) i jej potencjalnego wpływu na koszty obsługi kredytów walutowych. 


\section{ISTOTA KREDYTOWYCH EKSPOZYCJI DEWIZOWYCH}

Kredytowa ekspozycja dewizowa oznacza kwotę kapitału pozyskanego przez klienta $\mathrm{z}$ banku $\mathrm{w}$ formie kredytu, który jest denominowany lub indeksowany w stosunku do waluty obcej. Kredyt taki wystawia kredytobiorcę przede wszystkim na ryzyko zmiany kursu waluty obcej oraz zmiany jej oprocentowania. Ekspozycje wytwarzane w sektorze bankowym przez klientów detalicznych obejmują przede wszystkim długoterminowe hipoteczne kredyty mieszkaniowe, w tym zwłaszcza udzielane we frankach szwajcarskich ${ }^{1}$. Długi termin spłaty ww. kredytów powoduje, że ryzyka tworzone przez ich ekspozycje mają charakter strukturalny, oddziałujący na cały sektor bankowy i jego systemową wypłacalność. Ryzyko walutowe ekspozycji dewizowych ponoszone jest w pierwszej kolejności przez kredytobiorców, ale przy podwyższonym poziomie wahań kursów walut obcych oraz długim utrzymaniu niskiej wartości polskiego złotego, może relatywnie łatwo zamienić się w ryzyko kredytowe i bezpośrednio obciążyć banki. Możliwość przekształcenia się ryzyka rynkowego w kredytowe sprawia, że banki muszą zabezpieczać coraz wyższy kapitał regulacyjny oraz coraz bardziej aktywnie angażować się na rynku walutowym. Zwiększanie ekspozycji dewizowych w sektorze bankowym powoduje również nawarstwianie ryzyka ogólnogospodarczego, ponieważ NBP nie może sterować stopami procentowymi oraz kreacją pieniądza $\mathrm{w}$ walucie obcej. Jednym z kluczowych czynników potęgujących zagrożenia wynikające z kredytowych ekspozycji dewizowych w Polsce jest z pewnością młody wiek polskiego rynku kredytów hipotecznych oraz brak informacji i doświadczeń odnośnie do jego funkcjonowania w różnych fazach cyklu koniunkturalnego. Zagrożeniem zarówno dla poszczególnych klientów banków, jak i całego sektora bankowego w Polsce jest również bardzo wysoki wskaźnik LtV, którego średnia wartość na koniec 2010 r. wyniosła 76\%. Dla kredytów w walutach obcych wskaźnik ten osiągnął poziom $84 \%$. Na uwagę zasługuje przy tym fakt, że prawie $28 \%$ wartości kredytów mieszkaniowych stanowiły w tym czasie ekspozycje o wskaźniku LtV $80-100 \%$, a prawie $21 \%$ ekspozycje o LtV $>100 \%$ (Kwaśniak, 2011, s. 10). Podane parametry wskazują na bardzo wysokie obciążenie nieruchomości kredytami, a tym samym na brak realnej możliwości zabezpieczenia banków z tytułu udzielonych kredytów w warunkach zawirowań na rynkach finansowych. Dodatkowym problemem związanym z ekspozycjami dewizowymi jest także wydłużanie okresu kredytowania. W 2011 r. ok. 69\%

1 Udział mieszkaniowych kredytów hipotecznych we frankach szwajcarskich we wszystkich kredytach mieszkaniowych w walutach obcych kształtował się na poziomie od 93,5\% na koniec w 2009 r. do 83,4\% w październiku 2011 r. Zob. Dane, 2011. 
wartości kredytów mieszkaniowych pochodziło z ekspozycji przekraczających 25 lat (Kwaśniak, 2011, s. 8). Należy przy tym dodać, że ryzyko ekspozycji dewizowych o okresie 25-30 lat będzie obciążało klientów banków praktycznie przez cały czas ich aktywności zawodowej, a w wielu przypadkach także w okresie emerytalnym. Wydłużanie kredytowania pozwala na sztuczne podwyższenie zdolności kredytowej przez zmniejszenie wysokości raty kredytu, niemniej powoduje również znaczący wzrost łącznych kosztów odsetkowych kredytu w całym okresie kredytowania.

\section{RYZYKO KREDYTOWYCH EKSPOZYCJI DEWIZOWYCH Z PUNKTU WIDZENIA KLIENTA BANKU}

Zasadniczo klient zaciągający kredyt w walucie obcej będzie narażony na ryzyko zmiany kursu waluty obcej w stosunku do waluty krajowej. Ryzyko to bierze się z faktu, iż kapitał kredytu jest wyceniony w walucie obcej, natomiast przedmiot zakupu oraz spłata kredytu następuje w walucie krajowej, po bieżącym kursie rynkowym. Ponieważ utworzenie kredytowej ekspozycji dewizowej oznacza przyjęcie przez kredytobiorcę krótkiej pozycji na rynku walutowym, stąd wzrost kursu walutowego będzie powodował zwiększenie rat kredytu przeliczanych na polskie złote, natomiast spadek ich zmniejszenie. Ryzyko kursowe w szczególności uwidoczniło się w okresie kryzysu na rynkach finansowych, począwszy od lipca 2008 r., kiedy odwrócony został czteroletni trend umacniania polskiego złotego. Wartość długu kredytobiorców zaciągających kredyty we frankach 31 lipca 2008 r., a więc przy najniższym kursie tej waluty, do dnia 30 listopada $2011 \mathrm{r}$. wzrosła o $89,4 \%{ }^{2}$.

Kolejnym ryzykiem, jakie powstaje w przypadku kredytowania w walucie obcej jest niski wkład własny. Ryzyko to jest pochodną zmiany kursu walutowego i pojawia się w sytuacji, kiedy wartość kredytu w przeliczeniu na polskie złote zacznie odbiegać od wartości nieruchomości zabezpieczającej kredyt. Ryzyko to będzie powodowało w praktyce konieczność pokrycia przez kredytobiorcę kosztów dodatkowego ubezpieczenia kapitału kredytu, będącego różnicą pomiędzy całkowitą wartością zadłużenia wyrażoną w polskich złotych a $80 \%$ wartości nieruchomości³.

2 Obliczenia własne na podstawie danych NBP.

3 Banki zasadniczo wymagają zabezpieczenia kredytu w postaci wniesienia przez klienta przy zakupie nieruchomości przynajmniej $20 \%$ wkładu własnego. Próg ten jest narzucony regulacjami Rekomendacji T KNF. Dopuszczalna jest jednak sytuacja kredytowania klienta bez dostarczenia przez niego wymaganego wkładu własnego. Wówczas konieczne jest ubezpieczenie kredytu od dodatkowego ryzyka braku odpowiedniej wartości wkładu własnego. Zob. Rekomendacja T, 2010. 
Następnym rodzajem ryzyka towarzyszącego kredytowaniu walutowemu jest ryzyko marży kursowej (spreadu). Spread jest jednym z integralnych elementów kosztów kredytów stanowi różnicę pomiędzy kursem sprzedaży i kursem skupu waluty w banku. W praktyce obciąża on przede wszystkim tych klientów, którzy otrzymali kredyty w walucie obcej, a dokonują ich spłaty w walucie krajowej. Materializacja spreadu następuje z jednej strony w momencie wypłaty kredytu, którego kwota zostaje przeliczona na polskie złote po kursie skupu (niższym), $\mathrm{z}$ drugiej zaś w momencie spłaty rat kredytu, które przeliczane są na walutę obcą po kursie sprzedaży (wyższym). W polskiej praktyce bankowej spread dla kredytów mieszkaniowych dla poszczególnych walut zawiera się w przedziale: CHF 3,04-10\%, EUR 3,82-10,65\%, USD 4,27-10,53\% ${ }^{4}$. Średnia i mediana spreadu walutowego dla sektora bankowego wynoszą odpowiednio: CHF 6,57 i 6,22\%, EUR 6,38 i 6,19\%, USD 6,22 i 6,18\%. Ryzyko spreadu w praktyce oznacza możliwość zmiany jego wysokości w trakcie kredytowania, w tym zwłaszcza jego rozszerzenia w warunkach kryzysu na rynkach finansowych. Ponieważ coraz więcej banków podaje kredytobiorcom spread w postaci procentowej lub kwotowej, dlatego osoby te mogą coraz lepiej monitorować jego zmiany. Niemniej należy pamiętać, że ryzyko spreadu może przejawiać się także w przesuwaniu jego stałego zakresu względem kursu średniego NBP. W przypadku przesunięcia spreadu w dół kursu średniego bank będzie osiągał dodatkowe zyski (dyskontował korzyści) w momencie wypłacania kredytów klientom, natomiast w przypadku przesunięcia w górę, w momencie spłaty rat przez klientów.

Ostatnim kluczowym rodzajem ryzyk, obciążającym kredytobiorców tworzących ekspozycje dewizowe w walutach obcych, jest zmiana stóp procentowych tych walut. Kredyty hipoteczne o wieloletnim terminie spłaty zazwyczaj mają formułę oprocentowania według indeksowanej stopy pożyczek rynku międzybankowego, powiększonej o stałą marżę banku (np. WIBOR + marża, LIBOR + marża, EURIBOR + marża). Indeksacja realizowana jest na najczęściej w okresie $3 \mathrm{M}$ lub 6M. Stosunkowo rzadko w kredytach hipotecznych stosuje się oprocentowanie stałe, które nie zmienia się w całym okresie kredytowania. Zastosowanie formuly indeksowanej stopy procentowej oznacza przerzucenie ryzyka zmian ceny pieniądza na rynku międzybankowym na kredytobiorców. Zastosowanie stopy stałej oznacza przejęcie ryzyka przez bank. Na rynku finansowym oferty ze stałą stopą procentową będą raczej należały do rzadkości. W praktyce kredytowanie w walutach obcych powoduje uzależnienie kredytobiorcy od kondycji gospodarczej, zjawisk inflacyjnych oraz cyklu koniunkturalnego gospodarki innego

4 Dane na dzień 06.12.2011 pochodzące z 26 dużych i średnich banków komercyjnych najbardziej aktywnych w udzielaniu kredytów hipotecznych. Zob. szerzej http://www.spred.pl/waluta, 06.12.2011. 
kraju (w przypadku polskich kredytobiorców - przede wszystkim Szwajcarii). Zjawisko to może być niekorzystne z punktu widzenia spłacających kredyty przede wszystkim w przypadku braku pokrywania się cykli koniunkturalnych. W szczególności zagrożenie będzie stanowiła sytuacja pogorszenia kondycji finansowej kredytobiorców na skutek spowolnienia gospodarczego i recesji na rynku macierzystym, przy jednoczesnym wzroście oprocentowania kredytu hipotecznego, spowodowanym przyspieszonym rozwojem gospodarki, wzrostem inflacji i stóp procentowych w kraju waluty kredytowania. W przypadku polskich kredytobiorców zmiana stóp procentowych w Szwajcarii okazała się dla nich niezwykle korzystna, prowadząc do spadku stopy LIBOR 3M w okresie od 31 lipca 2008 r. do 30 listopada 2011 z 2,7558 do 0,0517\%. Należy jednak przyjąć, że końcowa wartość stopy procentowej nie odzwierciedla rzeczywistej, normalnej kondycji gospodarczej, ale stan kryzysowy.

\section{METODY ZARZĄDZANIA KREDYTOWĄ EKSPOZYCJĄ DEWIZOWĄ PRZEZ KREDYTOBIORCÓW}

Osoby fizyczne nieprowadzące działalności gospodarczej, które zaciągają kredyty w walutach obcych, a przy tym tworzą kredytowe ekspozycje dewizowe, mają relatywnie niewielkie możliwości zarządzania ryzykami wynikającymi z tych ekspozycji. W praktyce zarówno w bankach, jak i na rynku kapitałowym nie będą oni mieli powszechnego dostępu do instrumentów i technik zabezpieczenia, dostosowanych do ich indywidualnych potrzeb (np. transakcji terminowych, opcji lub strategii opcyjnych). W ich przypadku podstawowe metody zabezpieczenia przed ryzykiem będą oparte na hedgingu naturalnym oraz hedgingu na rynku pieniężnym. Jednocześnie należy dodać, że kredytobiorcy praktycznie nie będą mogli zarządzać ryzykiem zmiany stóp procentowych ekspozycji dewizowych $^{5}$.

Hedging naturalny oznacza kompensatę wpływów i wydatków w tej samej walucie. W przypadku polskich kredytobiorców oznaczałoby to konieczność uzyskiwania dochodów np. przede wszystkim we frankach szwajcarskich bądź euro. Hedging naturalny oznacza spłacanie rat kredytu wyliczonych w walucie obcej, wpływami w tej samej walucie otrzymywanymi przez kredytobiorcę np. z tytułu umowy o pracę. W praktyce powyższe działanie oznacza nałożenie na krótką

5 Ze względu na brak możliwości zmiany formy oprocentowania ze zmiennego na stałe, kredytobiorcy będą mogli jedynie dobierać krótszy lub dłuższy termin indeksacji zmiennej stopy procentowej dla waluty obcej (LIBOR 3M lub 6M). 
pozycję walutową kredytu (zobowiązanie), pozycji długiej, jaką stanowią wpływy w tej samej walucie (aktywa). W efekcie kredytobiorca domyka pierwotną pozycję walutową kredytu i uodparnia się na ryzyko strat (ale również eliminuje zyski). Ponieważ na polskim rynku finansowym klienci banków zasadniczo nie utrzymują depozytów we frankach szwajcarskich ani nie mają regularnych wpływów w tej walucie na rachunki ROR, stąd wykorzystanie hedgingu naturalnego dla tej waluty wydaje się bardzo ograniczone. Ze względu na większą liczbę osób zarabiających za granicą w euro lub funtach brytyjskich, dla tychże walut hedging naturalny będzie łatwiejszy do zrealizowania w praktyce.

Jedną z podstawowych metod zabezpieczenia stosowanych $w$ ramach hedgingu na rynku pieniężnym jest przewalutowanie kredytu $\mathrm{z}$ waluty zagranicznej na walutę krajową lub z waluty krajowej na zagraniczną. W obu przypadkach dług klienta $\mathrm{w}$ jednej z walut zostaje przeliczony na drugą. Przewalutowanie powinno być dokonane tak, aby za bieżącą kwotę długu kupić jak najmniej jednostek drugiej waluty. W praktyce będzie to oznaczało, że zamiany kredytu z waluty obcej na krajową dokonuje się w sytuacji, kiedy waluta obca jest skrajnie tania. Przewalutowania z waluty krajowej na walutę obcą dokonać należy w sytuacji odwrotnej. Ponieważ rzadko kiedy bank, który specjalizuje się w kredytach walutowych, będzie miał jednocześnie najlepszą ofertę kredytów w walucie krajowej lub odwrotnie, dlatego też przewalutowanie z powodzeniem może zostać zastąpione refinansowaniem kredytu $\mathrm{w}$ innym banku, oferującym $\mathrm{w}$ danym momencie na rynku najlepsze warunki kredytowania. Proces refinansowania pozwala dodatkowo ominąc prowizję, która zazwyczaj występuje przy przewalutowaniu kredytu.

Inną metodą zarządzania kredytową ekspozycją dewizową w ramach hedgingu na rynku pieniężnym jest dokonywanie nadpłat rat kredytu. Nadpłaty te pozwalają na gromadzenie dodatkowego kapitału w walucie krajowej, który stanowi swego rodzaju bufor oszczędnościowy. Bufor ten będzie miał za zadanie skrócić okres kredytowania, a przy tym zmniejszyć łączne koszty kredytu z tytułu odsetek. Nadpłaty stanowiące wymieniony bufor powstają w wyniku odkładania na osobny rachunek różnicy pomiędzy kwotą środków, jakie klient spłaca z tytułu równych rat kredytu a kwotą, jaką spłacałby, gdyby korzystał z metody malejących rat kredytu. W efekcie do czasu zrównania obu kwot, pozycja płatnicza klienta wygląda tak, jakby spłacał on kredyt w ratach malejących, przy jednoczesnej redukcji długu wobec banku według rat równych. W momencie zrównania kwoty zadłużenia pozostającego do spłaty oraz wartości bufora oszczędnościowego następuje przedterminowa spłata kredytu. Należy przy tym dodać, że przedterminowa spłata kredytu będzie miała sens tylko wtedy, gdy oprocentowanie kredytu w walucie obcej będzie mniejsze niż oprocentowanie rachunku, na którym gromadzone są nadpłaty utrzymywane w walucie krajowej. 


\section{ZARZĄDZANIE EKSPOZYCJĄ DEWIZOWĄ A REKOMENDACJE KOMISJI NADZORU FINANSOWEGO}

Ze względu na znaczną liberalizację polityki kredytowej banków, obniżanie wymogów w procesie oceny zdolności kredytowej, nadmierne wydłużanie okresu kredytowania, akceptowanie nadmiernego obciążania klientów kredytami (przekredytowanie), udzielanie kredytów o wartościach znacznie przekraczających $80 \%$ LtV oraz przyjmowanie zbyt optymistycznych założeń co do wzrostu gospodarki oraz cen nieruchomości Komisja Nadzoru Finansowego przygotowała łącznie trzy rekomendacje dobrych praktyk kredytowania hipotecznego klientów detalicznych, w tym w walutach obcych (S, SII i T). Rekomendacje te zawierają propozycję działań, które powinny zostać podjęte przez banki w obszarach: polityki kredytowej, systemów zarządzania ryzykiem, dokonywania oceny zdolności kredytowej klienta, ustanawiania zabezpieczeń kredytów, jak również kształtowania relacji z klientami. Jednym z ważniejszych postanowień rekomendacji jest umożliwienie klientom zamiany sposobu spłaty kredytu indeksowanego w stosunku do waluty obcej na spłaty w walucie indeksacji. Rozwiązanie to wprowadza nową jakość zarządzania ekspozycjami dewizowymi, ponieważ pozwala klientom banków uniknąć przeliczania waluty obcej na polskie złote w banku udzielającym kredytu oraz w dniu spłaty raty. Kredytobiorcy uzyskali tym samym możliwość nabywania walut w dowolnym miejscu i czasie, tak aby mogli minimalizować zarówno spread, jak również cenę zakupu. Jednocześnie rozwiązanie to daje podstawę do stworzenia konkurencji pomiędzy bankami i innymi instytucjami finansowymi w zakresie obrotu walutowego.

\section{ZARZĄDZANIE KREDYTOWĄ EKSPOZYCJĄ DEWIZOWĄ A USTAWA „ANTYSPREADOWA”}

Ustawa antyspreadowa, a właściwie Ustawa z dnia 29 lipca 2011 r. o zmianie ustawy - Prawo bankowe oraz niektórych innych ustaw, stanowi dopełnienie i jednocześnie rozwinięcie zasad zawartych w rekomendacjach. Regulacje ustawy antyspreadowej zostały opracowane przede wszystkim z myślą o kredytobiorcach, którzy zaciągnęli walutowe kredyty hipoteczne denominowane lub indeksowane w stosunku do franka szwajcarskiego. Niemniej z zapisów tej ustawy mogą także korzystać osoby mające kredytowe ekspozycje dewizowe z innych tytułów niż kredyty mieszkaniowe. Generalnie ustawa antyspreadowa nakazuje bankom określać szczegółowe zasady ustalania kursów wymiany walut służących wyliczaniu rat oraz określać zasady przeliczania waluty obcej na krajową 
w momencie wypłaty kredytu albo dokonywania jego spłaty. Wymieniona ustawa daje możliwość spłaty rat lub przedterminowej spłaty kredytu bezpośrednio w walucie kredytowania, bez konieczności przeliczania ekspozycji na polskie złote. Według przyjętego aktu prawnego banki zostały również zobowiązane do określania zasad otwarcia i prowadzenia rachunków walutowych, służących do gromadzenia środków przeznaczonych na spłatę kredytu oraz zasad spłaty z wykorzystaniem takich rachunków. Zastrzeżono również, że klienci nie mogą ponosić dodatkowych kosztów w związku ze spłatą kredytu bezpośrednio w walucie, a rachunki, które służą takiej spłacie, muszą być prowadzone nieodpłatnie. Zgodnie z rozważaną ustawą, niezależnie od formy spłaty wybranej przez klienta (gotówkowa lub bezgotówkowa), banki nie mogą obciążać go dodatkowymi kosztami obsługi walutowej. Niedopuszczalne jest również zobowiązanie kredytobiorców do nabywania waluty przeznaczonej na spłatę rat kredytu, jego całości lub części, od określonego podmiotu.

Oceniając rozwiązania prawne wprowadzone ustawą ,antyspreadową”, należy podkreślić ważność uprawnienia do zakupu waluty poza bankiem kredytującym oraz poza rynkiem bankowym. W praktyce uprawnienie to daje klientom możliwość nabycia walut obcych w miejscach, które charakteryzują się relatywnie niskimi spreadami. Zakup walut może odbywać się także w dowolnym momencie, a nie w dniu spłaty raty kredytu (tak jak w przypadku kredytów indeksowanych do waluty obcej), co ma bardzo duże znaczenie w procesie zarządzania ryzykiem kursu walutowego. Kredytobiorcy mogą bowiem zaopatrywać się w walutę w tych dniach, kiedy kurs jej jest np. wyjątkowo niski.

Możliwość kupowania waluty poza bankiem i spłacanie nią kredytu hipotecznego jest z pewnością właściwością pożądaną, ale nie rozwiązuje wszystkich problemów kredytobiorców. Klienci korzystający np. z usług kantorów, a nie banków, mogą otrzymać niższy spread, wahający się od ok. 1 do ok. 5\%. Niemniej w określonym regionie/mieście kursy walutowe na skutek braku konkurencji pomiędzy kantorami mogą być niewiele korzystniejsze od bankowych. W takiej sytuacji, po doliczeniu czasu dotarcia do kantoru, kosztu np. paliwa i parkingu, a także czasu dotarcia do oddziału banku, stosowanie zewnętrznej wymiany walutowej może nie dawać realnych korzyści. Ograniczeniem może być również brak w kantorach odpowiednich zasobów walut obcych, które będą kupowane przez klientów i przenoszone do banków tytułem spłaty rat kredytu. Zwłaszcza pod znakiem zapytania może stać wystarczalność zasobów franków szwajcarskich, które nie są zwykle dostarczane do kantorów przez turystów, ale kupowane w bankach. W takiej sytuacji nadmierna presja popytowa może prowadzić do całkowitego wykupienia franków lub wzrostu ich kursu w kantorach do poziomu kursu w bankach. Kolejnym problemem związanym z pozyskaniem walut w kantorach może być również brak oddziału banku lub brak kasy walutowej 
w oddziale banku w miejscu zamieszkania kredytobiorcy. Sytuacja taka uniemożliwi obsługę gotówkową spłaty kredytu. Z punktu widzenia kredytobiorców ograniczenia wystąpią również w przypadku bezgotówkowej obsługi kredytu, kiedy waluta kupowana jest $\mathrm{w}$ innym banku, u niebankowego dealera walutowego bądź w internetowym kantorze. W tym przypadku kredytobiorca poniesie koszty transferu środków z konta sprzedawcy na swoje własne konto walutowe, z którego będzie spłacał kredyt. O ile transfer euro jest relatywnie niskokosztowy ze względu na wykorzystanie działających w Polsce systemów rozliczeniowych dla tej waluty (EuroElixir oraz TARGET2-NBP), o tyle transfer innych walut odbywa się za pośrednictwem systemu bankowości korespondenckiej SWIFT i wiąże się ze znacznie wyższymi opłatami (zwykle ok. kilkudziesięciu złotych). Podwyższone koszty będą tym samym ograniczały opłacalność transakcji bezgotówkowych związanych z obsługą kredytów.

\section{PODSUMOWANIE}

Klienci banków zaciągający wieloletnie walutowe mieszkaniowe kredyty hipoteczne wystawieni są na ryzyko (zwłaszcza zmiany kursu walutowego, spreadu, niskiego wkładu własnego i zmiany stopy procentowej) towarzyszące im w długim horyzoncie czasowym. Jednocześnie mają bardzo ograniczone możliwości zarządzania wymienionymi rodzajami ryzyka. Jedyne metody i narzędzia stosowane przez nich opierają się właściwie na kompensacie płatności w walucie obcej lub zabezpieczeniu na rynku pieniężnym. Ze względu na to, iż znacząca cześć kredytobiorców w Polsce zaciągnęła kredyty hipoteczne w walutach obcych, można oczekiwać, że wprowadzone zmiany legislacyjne, dające klientom banków większą swobodę w pozyskiwaniu walut i ich wykorzystaniu do spłaty kredytów, przyczynią się do korzystniejszej wyceny walut w bankach i spowodują obniżkę ogólnych kosztów kredytowania walutowego. Wprowadzenie w 2011 r. ustawy antyspreadowej nie spowodowało, jak do tej pory, znaczącego, widocznego z punktu widzenia całego systemu finansowego obniżenia spreadów i zwiększenia opłacalności wymiany walutowej na rynku bankowym. Ze względu na brak dostatecznie rozwiniętej struktury pozabankowego rynku walutowego oraz relatywnie wysokie koszty transferu walut obcych systemem SWIFT, nie należy spodziewać się w krótkim okresie masowego przenoszenia zakupu walut do innych podmiotów niż banki udzielające walutowych kredytów hipotecznych. Znaczący udział zysków z handlu walutami, jakie osiągają banki w obecnych warunkach, będzie skłaniał raczej do podtrzymania wysokości spreadu aż do czasu wytworzenia na polskim rynku realnych mechanizmów konkurencji 
w obrocie walutami. Urzeczywistnienie korzyści wynikających z ustawy antyspreadowej nastąpi najprawdopodobniej dopiero wtedy, gdy na polskim rynku będzie pojawiała się coraz większa liczba niezależnych dealerów walutowych lub rozwinie się sprzedaż walut obcych przez kantory internetowe prowadzące rachunki walutowe w wielu bankach. Dzięki takiemu rozwiązaniu może dojść do zaostrzenia konkurencji w handlu walutami na całym rynku finansowym oraz likwidacji kosztów transferu, obciążających klientów. Jednocześnie w systemie finansowym w Polsce powstanie kolejny problem - uregulowania i wprowadzenia nadzoru nad tym segmentem rynku.

Optymalnym kierunkiem rozwoju rynku walutowych kredytów hipotecznych powinno być kredytowanie w walucie krajowej, a więc w walucie, w jakiej uzyskuje się dochody. W tym przypadku konieczne jest obniżenie stóp procentowych do poziomu zbliżonego do innych walut krajów wysoko rozwiniętych. Obniżka taka możliwa jest jedynie w warunkach niskiej inflacji. Jednocześnie powinno się dążyć do dalszego ograniczenia dostępu do kredytów walutowych we frankach szwajcarskich, ze względu na podwyższoną zmienność i spekulacyjny charakter wymienionej waluty.

\section{LITERATURA}

Dane miesięczne, Urząd Komisji Nadzoru Finansowego, Warszawa 2011, http://www. knf.gov.pl/opracowania/sektor_bankowy/index.html.

http://www.spred.pl/waluta.

Kwaśniak W., Poprawa bezpieczeństwa rynku kredytów mieszkaniowych w aspekcie polityki nadzorczej, Komisja Nadzoru Finansowego, Warszawa 2011, s. 10.

Rekomendacja S (II) dotyczaca dobrych praktyk w zakresie ekspozycji kredytowych zabezpieczonych hipotecznie, Komisja Nadzoru Bankowego, Warszawa 2006.

Rekomendacja S dotyczaca dobrych praktyk w zakresie ekspozycji kredytowych zabezpieczonych hipotecznie, Komisja Nadzoru Bankowego, Warszawa 2006.

Rekomendacja T dotyczaca dobrych praktyk $w$ zakresie zarzadzania ryzykiem detalicznych ekspozycji kredytowych, Komisja Nadzoru Finansowego, Warszawa 2010.

Sektor bankowy. Podstawowe dane. Urząd Komisji Nadzoru Finansowego, Warszawa 2009, http://www.knf.gov.pl/opracowania/sektor_bankowy/dane_o_rynku/Dane_ kwartalne.html.

Ustawa z dnia 29 lipca 2011 r. o zmianie ustawy - Prawo bankowe oraz niektórych innych ustaw, Dz.U. 2011, nr 165, poz. 184. 


\section{MANAGEMENT OF CREDIT CURRENCY EXPOSURES - BANK CLIENTS PERSPECTIVE}

A b s tract. The paper contains the description of problem of credit currency exposure created by foreign currency mortgage loans in Polish banking system. At present foreign currency mortgage loans concentrate the biggest share of all bank assets in Poland. They bring many types of risk to the commercial banks as well as to their clients. As such loans are mostly granted for very long periods (usually more than 25 years), they usually exceed $80 \%$ of LtV ratio as well as they are denominated in Swiss francs, thus they significantly increase the systematic risk of whole banking sector. Their threat of insolvency of Polish debtors is very serious, but the bank clients have very few instruments allowing managing foreign currencies loans exposures. One of the latest instruments of its management is coming from an amendment to the banking law, called anti-spread act.

K e y word s: exposure, risk, recommendation, anti-spread act. 